\title{
THE CLINICAL PATHOLOGY OF RHEUMATIC MITRAL ENDOCARDITIS
}

\author{
BY
}

\section{J. C. VAN DER SPUY}

From Pretoria General Hospital and University of Pretoria, Republic of South Africa

Received April 14, 1962

The correct pre-operative assessment of the morbid anatomy of the mitral valve is obviously of the greatest importance as it will help the surgeon to determine, amongst other things, whether relief of the stenosis is likely to produce or to aggravate any associated regurgitation, whether the operation should be done by closed- or open-heart methods, and whether repair of, or possibly even replacement of, the anterior or the posterior or both cusps will be required.

Before discussing the pathogenesis, the morbid anatomy, and the clinical pathology of the rheumatic mitral valve, it will be necessary to refer briefly to certain aspects of the normal anatomy and to the mechanism of closure of the normal and of the stenosed mitral valve (Van der Spuy, 1958).

Anatomy of Normal Mitral Valve. The mitral valve functions as a unit. This unit consists of a "ring," of two unequal, somewhat triangular cusps, of two sets of papillary muscles, and of numerous chordæ tendineæ. Of the two cusps the antero-medial (anterior) cusp is much the longer and it is attached, with the major part of two adjacent aortic cusps, to the root of the posterior half of the aorta (Fig. 1). As seen from the left ventricular aspect, the base of the anterior cusp, i.e. the anterior half of the mitral "ring", is therefore bi-concave. As, however, the anterior half of the left atrium is attached across the upper surface of the base of the anterior cusp close to the "ring," the anterior half of the ring as seen from the left atrial aspect is semi-ovoid. The shorter postero-lateral (posterior) cusp is attached with the corresponding part of the base of the left ventricle to the posterior half of the mitral "ring." As the apical zones of the two cusps correspond, the body of the longer anterior cusp lies opposite the base of the shorter posterior cusp. The anterior cusp, being suspended from the posterior half of the root of the aorta, in the resting position is convex posteriorly, whereas the posterior cusp, attached to the base of the left ventricle, is concave anteriorly. During valve closure the convexity of the anterior cusp fits into the concavity of the posterior cusp.

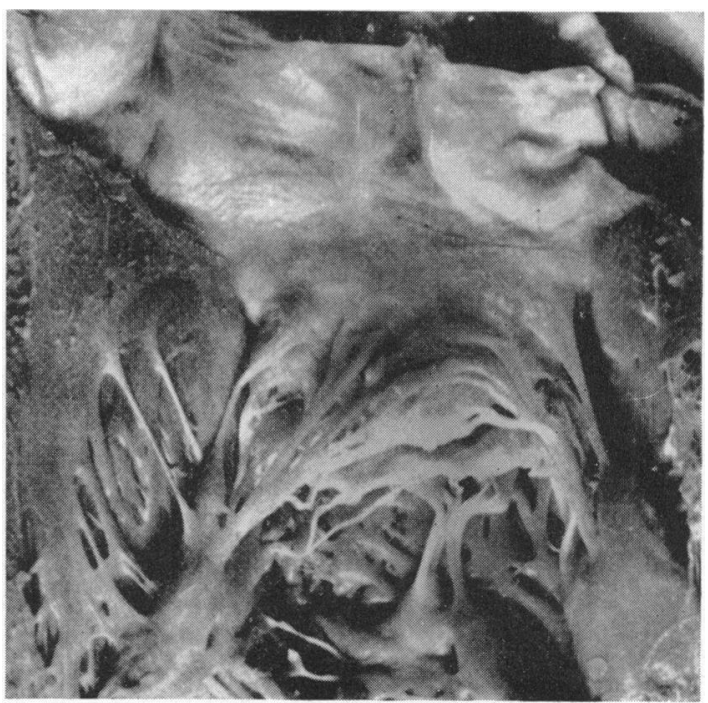

FIG. 1.-The antero-medial cusp of the mitral valve is attached with the major part of two adjacent aortic cusps to the root of the posterior half of the aorta. 
Each of the two papillary muscle groups arises from the ventricular wall opposite but distal to a valve commissure.

The branching chordæ tendineæ connect the apical zones of one group of papillary muscles to the margins and under-surfaces of the ipsolateral halves of the cusps. The chordæ tendineæ of the anterior cusp are attached only to the cusp's peripheral zone (Fig. 2). The remaining main body of the cusp is, therefore, much thinner than this peripheral zone and also much more mobile as its excursions are not directly restricted by the chordæ. During systole, the body of the anterior cusp can, therefore, billow upwards and backwards to fit snugly into the concave base of the posterior cusp. The chordæ tendineæ of the posterior cusp, however, are inserted into almost its entire undersurface, excluding the basal zone (Fig. 3). In their course from the apices of the papillary muscles to

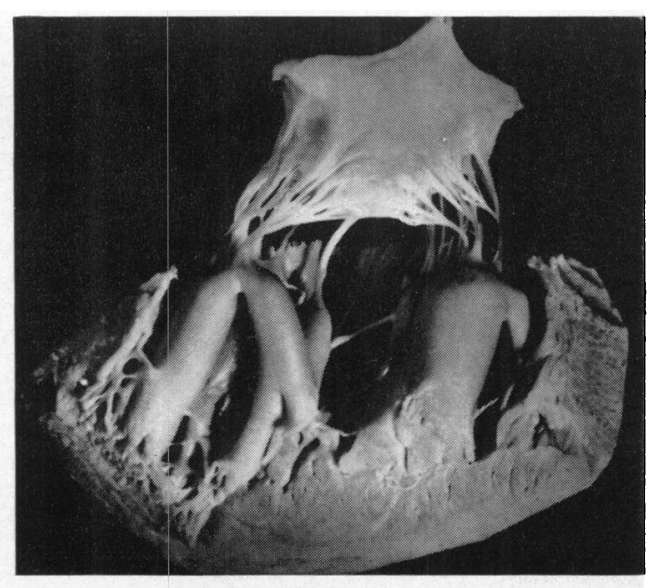

FIG. 2.-The chordæ tendineæ of the antero-medial cusp are attached only to the peripheral zone of the cusp. The central portion of the cusp is, therefore, thinner and more mobile.

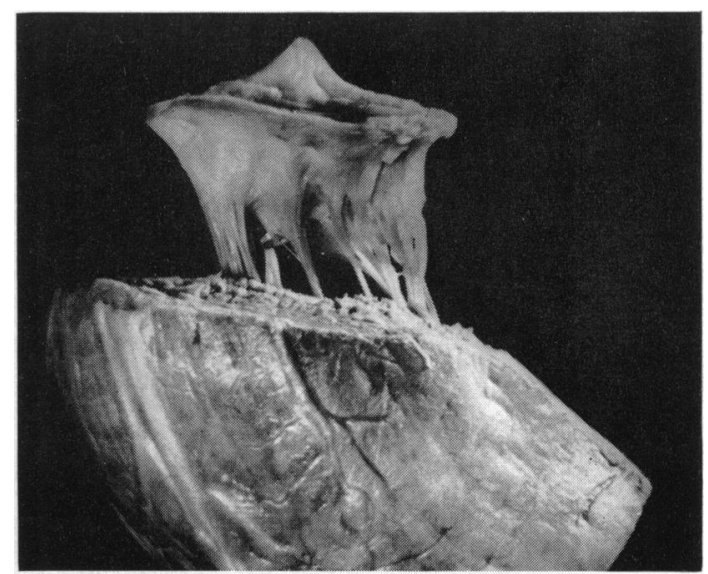

FIG. 3.-The chordæ tendineæ of the postero-lateral cusp are attached to the entire under surface of the cusp, excluding the basal zone.

the cusps, the main stems of the chordæ tendineæ break up into numerous fine tendinous filaments. On the under-surfaces of the cusps they expand into flat, somewhat triangular sheets which are attached to the cusps at acute angles resulting in the formation of many small nooks and crevices (Fig. 4).

Normal Mechanism of Mitral Valve Closure. At the onset of systole, as the pressure in the left ventricle exceeds that in the left atrium, the anterior cusp, suspended from the root of the aorta, swings backwards and upwards towards the posterior cusp, whereas the latter, attached to the base of the left ventricle, swings forwards and upwards towards the anterior cusp. The cusp rotation is initiated, its direction determined, and its extent limited by the pulling effect of the papillary muscles, via the chordæ tendineæ, on the ipsolateral commissural and apical zones of the cusps (Fig. 5). Once the cusp margins have made contact the valve is closed, although not firmly so. As systole progresses and as there is as a result a progressive rise in left ventricular pressure, so there is a progressive increase in the area of cusp surface contact until the anterior cusp, having reached its maximal upward excursion, fits into the base of the posterior cusp. At this stage a large portion of the anterior cusp, being much longer than the posterior cusp, billows towards the left atrium above the level of the closed valve. The sudden arrest in the upward excursion of this portion of the anterior cusp is very largely responsible for the production of the first heart sound in the mitral area. 


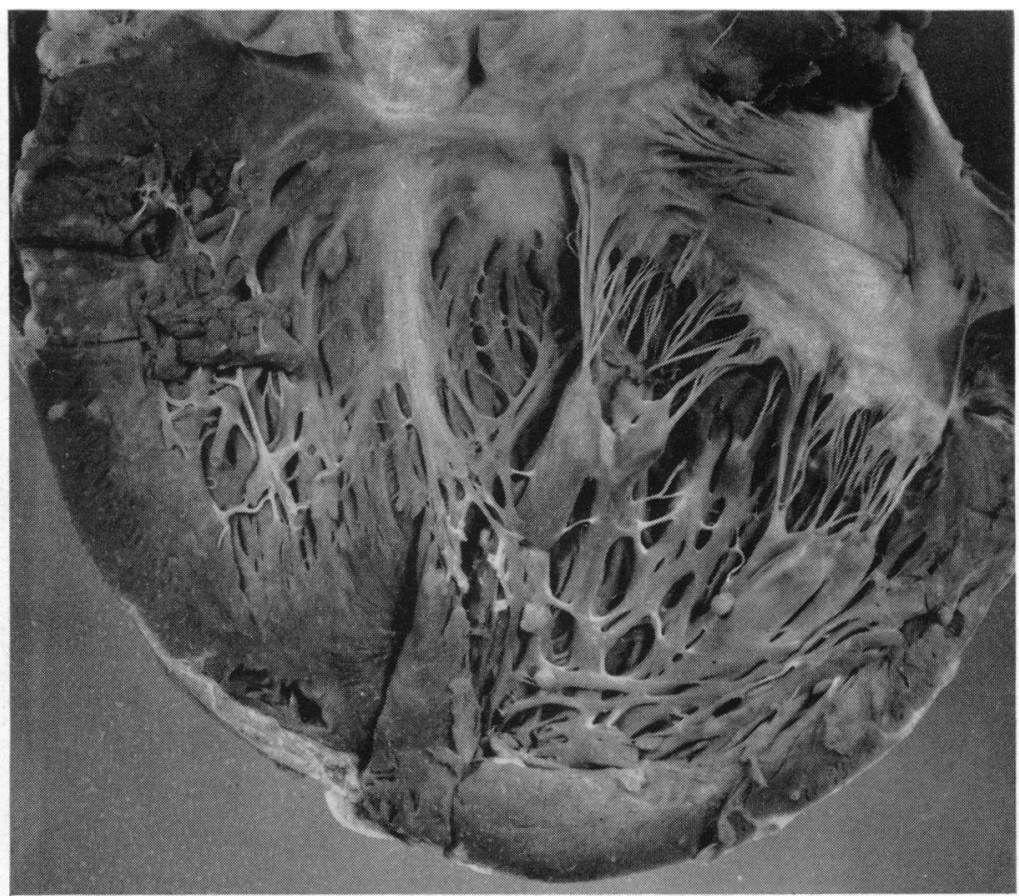

FIG. 4.-In their course from the apices of the papillary muscles to the cusps, the chordæ tendineæ break up into numerous fine filaments. On the undersurfaces of the cusps they expand into flat, somewhat triangular, sheets, which are attached to the cusps at acute angles, thereby forming many small nooks and crevices.

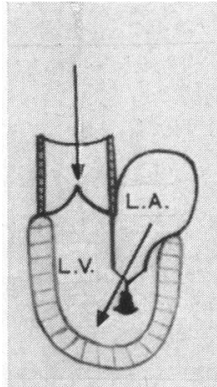

DIASTOLE

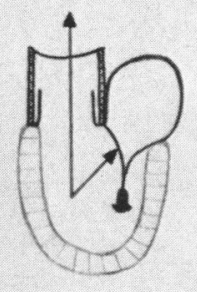

EARLY SYSTOLE

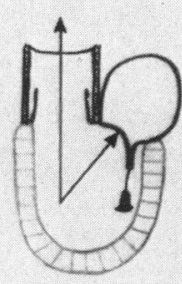

FIG. 5.-The normal mechanism of mitral valve closure-see text. 
Closing Mechanism of Stenosed Valve. The stenosed mitral valve anatomically as well as functionally is incompetent. Because of the presence of the firm, oval, stenotic opening, the apex of the mitral valve cone cannot close at the beginning of systole. As the pressure in the left ventricle rises, valve closure is produced by the anterior cusp being forced against the base of the posterior cusp above the incompetent stenotic opening. This early systolic incompetence produces the characteristic pre-M1 murmur which is incorrectly spoken of as a presystolic murmur (Fig. 6).

\section{Pathogenesis of Mitral Rheumatic Endocarditis}

The characteristic valve lesions found in mitral rheumatic endocarditis are the result of both valvulitis and tendinitis. The tendinitis plays a very much more important role than is generally appreciated, and it is probably of much greater significance in the production of incompetence, and even perhaps of stenosis, than the valvulitis. As a result of a fibrinous deposit on the surface of the chordæ tendineæ, the fine filaments fuse together and become thickened (Fig. 7). Subsequently,

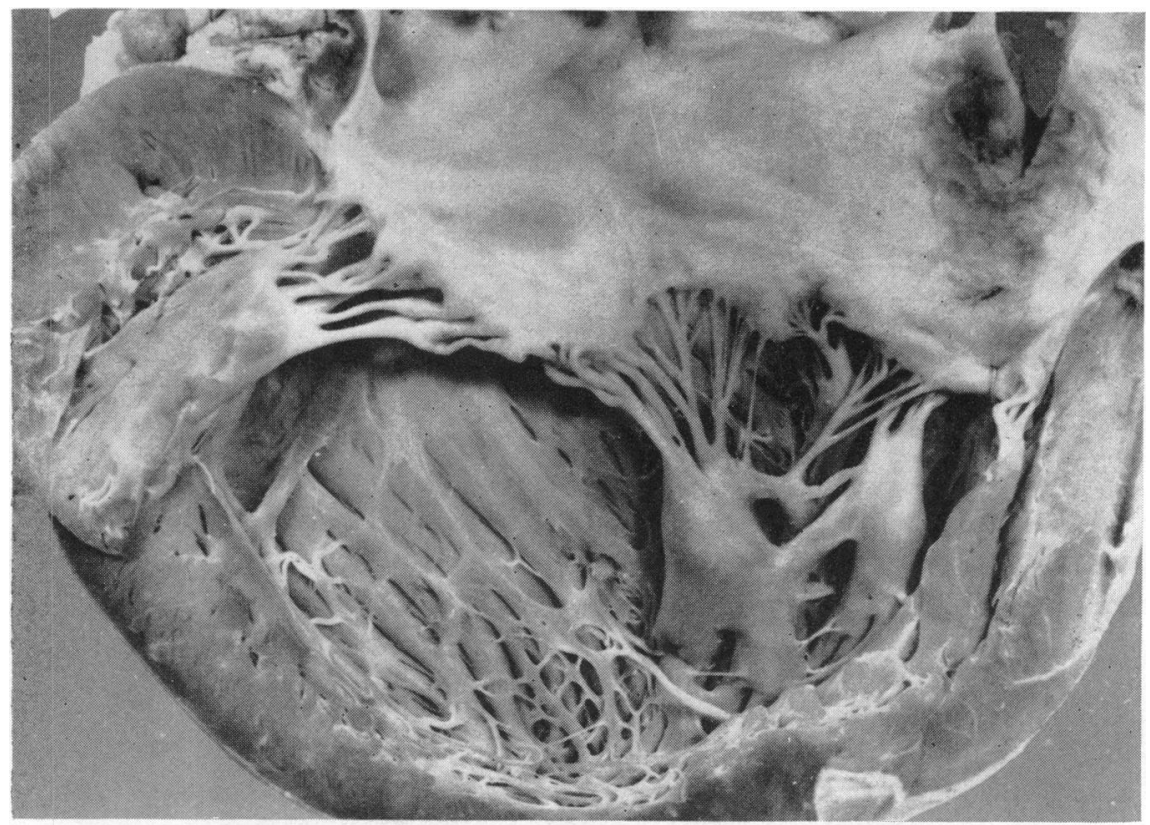

FIG. 7.-Rheumatic tendinitis first causes fusion with thickening of the chordæ later followed by shortening. The fine filamentous chordæ tendineæ have become fused together as the result of the deposition, of fibrinous material, thereby causing thickening, but, as yet, hardly any shortening, of the chordæ. Due to the fibrinous deposit in the nooks and crevices on the under-surface of the peripheral zone of chiefly the anterior cusp, the cusp margin has become moderately thick.

due to infiltration by fibrous tissue the affected chordæ become shortened (Fig. 8). When the fibrinous material is deposited in the nooks and crevices on the under-surfaces of the cusps, thickening results which may become severe. The cusp that is the seat of active rheumatic endocarditis is œdematous and infiltrated by macrophages and fibroblasts with fibrin deposited on the surface. It later becomes infiltrated by fibrous tissue which also causes thickening of the cusp. Shortening of the cusp itself does not appear to be a very striking result of the valvulitis and shortening of the chordæ tendineæ is a feature that is of much greater significance as a cause of abnormal valve 


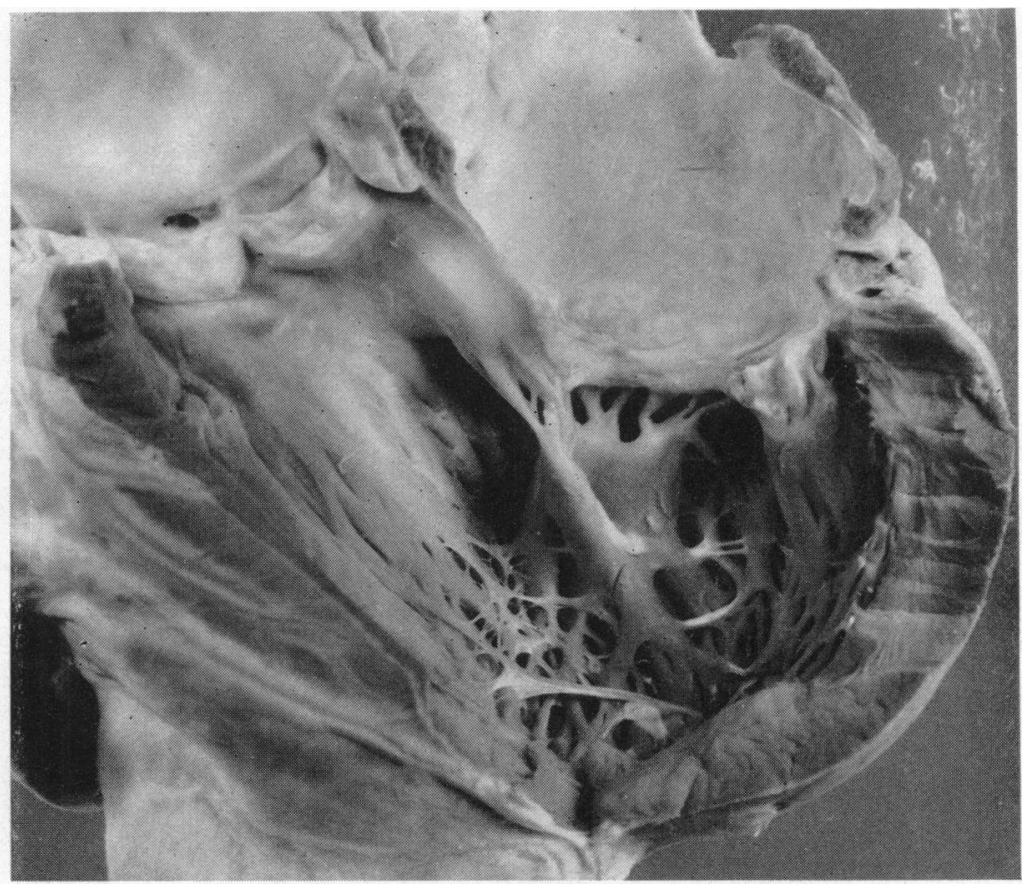

FIG. 8.-The fused and thickened chordæ tendineæ have become shortened. Note in particular that, although the systolic swing of the anterior cusp will be much reduced owing to the shortening of the chordæ, there is relatively little shortening of the cusp itself.

function. Fibrin deposited in the acute angle of the narrow valve commissures, between the fine filaments of the chordæ tendineæ and in the narrow slits between the latter and the commissural margins of the cusps, causes stenosis of the valve. In severe cases the valve commissures, chordæ, and papillary muscles may become one solid mass of tissue. The macroscopic involvement of the cusps and chordæ may be limited to but a part of the valve. On the other hand the whole valve may be affected. Thus the stenosis may be caused by the closure of one commissure only and the incompetence may be the result of shortening of the chordæ of one cusp or of one commissure (Fig. 9). Whether a valve will be stenotic or incompetent seems to depend largely on whether or not commissural closure takes place before chordal shortening. Once a valve has become fully stenosed, even though subsequent shortening of the chordæ and thickening of the cusps may completely prevent supra-stenotic valve closure, the regurgitation will be limited to the size of the stenotic opening. Should chordal shortening, however, occur first, then gross incompetence will take place, and significant subsequent commissural fusion cannot develop. Primary incompetence without any stenosis must be somewhat rare as this would postulate tendinitis, with chordal shortening, but without valvulitis and without the deposition of fibrin between the chordæ and commissural margins as described above.

\section{Clinical Assessment of Morbid Anatomy of Mitral Valve}

1. The First Heart Sound in Mitral Area. The thin and mobile body of the anterior cusp seems very largely responsible for this sound as in stenosis associated with incompetence of the posterior cusp M1 is loud and snapping (Van der Spuy, 1960). The quality of M1 is, therefore, an indication of the mobility and thickness of the mobile trigone of the anterior cusp. The less mobile and thicker 


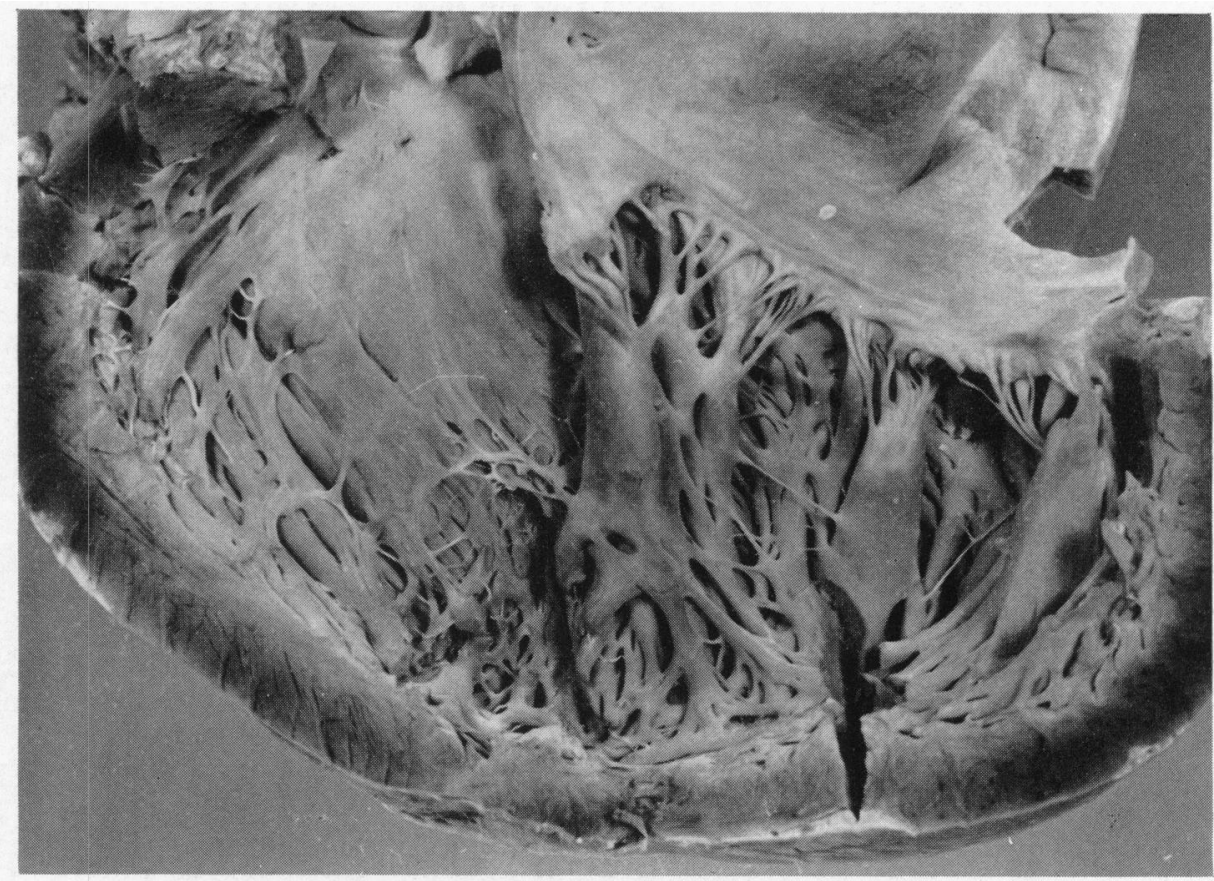

FIG. 9.-Eccentric tendinitis and valvulitis. The anterior cusp is thickened but not shortened. Mobility of this cusp was, however, seriously interfered with on account of the severe shortening of the chordæ tendineæ.

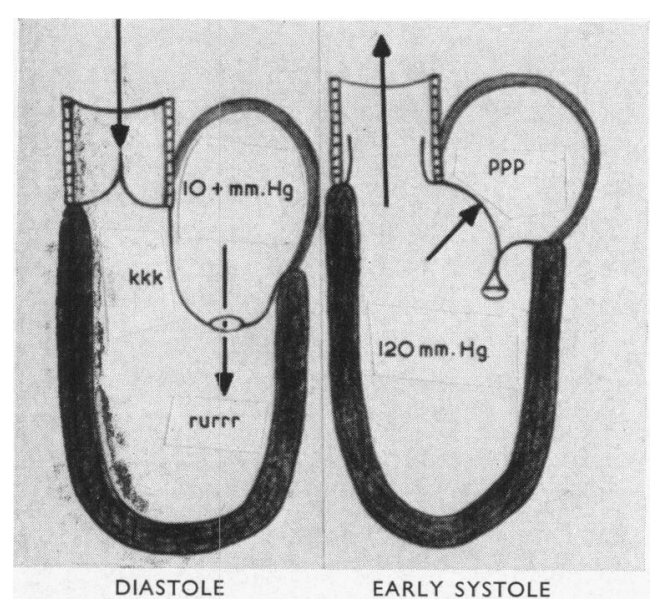

FIG. 10.-The opening snap-kkk-is the diastolic counterpart of a loud and snapping M1-ppp. The latter is produced when the body of the anterior cusp is brought to a sudden standstill at its point of maximal upward systolic excursion. The former results when the thin anterior cusp, with its margins fused to those of the posterior cusp, instead of swinging open at the beginning of diastole, billows downwards and comes to a sudden halt down towards the ventricle. the cusp, the softer and thicker M1 and the more imminent failure of the compensatory mechanism of valve closure, viz. suprastenotic cusp surface contact.

2. Opening Snap (Mounsey, 1953). This clicking sound that follows the second heart sound and immediately precedes the diastolic rumble is the diastolic counterpart of a loud and snapping M1. The latter is produced when the mobile trigone of the anterior cusp reaches its point of maximal excursion up towards the left atrium, whereas the opening snap is produced when the anterior cusp, with its margins fused to those of the posterior cusp, instead of swinging open at the beginning of diastole, comes to a sudden halt down towards the left ventricle (Fig. 10). As a loud and snapping M1 and the opening snap are produced by a thin and mobile anterior cusp and as the mobile trigone of this cusp is by far the most important single factor in suprastenotic valve closure, significant mitral incompetence is uncommon when these clinical signs are present. At the same time it will be apparent that gross incompetence due to fixity of the posterior cusp may exist in spite of clinical evidence of a thin and mobile anterior cusp. 
3. Diastolic Rumble. This murmur is related only to the diastolic flow across the stenotic opening and is entirely unrelated to the mobility of the cusps. The diastolic murmur will, therefore, be the same in a case of stenosis with thick immobile cusps, incapable of supra-stenotic closure, as in a case with the same degree of stenosis and thin cusps capable of valve closure.

4. Nature of Systolic murmur.

(a) Rrruppp.

Rrr-Pre-M1 murmur caused by incompetence through the apex of the valve cone before closure of the valve above the constantly-present incompetent opening.

uppp-The first heart sound is loud, abrupt, and high-pitched as the cusps are thin and mobile with complete supra-stenotic valve closure.

(b) Rrruppss.

Rrrr-Pre-M1 murmur.

upp —Loud, abrupt and high-pitched first heart sound.

ss-Short and soft systolic blowing murmur.

The cusps are thin and mobile with good supra-stenotic valve closure but with a small leak, probably through a commissure or due to shortening and thickening of the posterior cusp unit.

(c) Rroopshshsh.

$R r$--Short pre-M1 murmur

oop-First heart sound is soft and thick.

shshsh-Long blowing systolic murmur.

The cusps are thick and less mobile and the sound produced by the anterior cusp as it reaches its point of maximal upward excursion is just audible. Owing to the chordal shortening and cusp immobility supra-stenotic valve closure has failed, resulting in significant regurgitation.

(d) Rrooshshsh.

$R r$-Short pre-M1 murmur.

ooshshsh-Long blowing systolic murmur but without a definite first heart sound.

The cusps are thick and more or less immobile.

(e) Ddooshshsh.

$D d$-First heart sound not preceded by a pre-M1 murmur.

ooshshsh-Long blowing systolic murmur.

Although the anterior cusp is mobile, the valve is incompetent because of thickening and shortening of the posterior cusp and its chordæ tendineæ.

The loudness of the heart sound preceding the murmur, i.e. the D of Dooshshsh, indicates to what extent the excursions of the anterior cusp are restricted by chordal shortening and valve thickening.

(f) Shooshshsh-Long blowing systolic murmur without a pre-M1 murmur and without an audible first heart sound.

The anterior cusp is no longer mobile owing to marked thickening of the cusp and shortening of it chordæ. With this anterior cusp incompetence, there may or may not be an associated posterior cusp incompetence.

The following few examples should illustrate how the morbid anatomy of the mitral valve can be determined by the quality of the heart sounds and the nature of the murmurs.

Rrooshsh du (second heart sound) rurrrr (diastolic rumble).

The anterior cusp is thick and more or less immobile and incapable of meeting the posterior cusp above the stenotic opening in systole. The chordæ are thick and short and the valve is tightly stenosed. The incompetence is relatively small only because it is limited by the size of the stenotic opening. Relief of the stenosis will result in marked aggravation of the regurgitation.

Rrruppsss du-K ( $\mathrm{K}=$ opening snap) rurrrr, with evidence of left ventricular hypertrophy (Van der Spuy, 1960). 
The anterior cusp is thin and mobile, but incompetence of hæmodynamic significance is present due either to thickening of the posterior cusp with shortening of its chordæ tendineæ, or to commissural incompetence.

Similarly the significance of other mitral murmurs can be analysed, particularly when they are taken in conjunction with the absence or presence of left ventricular hypertrophy.

\section{SUMMARY}

An attempt has been made to correlate the clinical findings with the morbid anatomy of the mitral valve in patients suffering from rheumatic mitral endocarditis.

All the pathological specimens are bottled laboratory specimens. In no single instance could the clinical findings and the morbid anatomy of the same patient be studied. Furthermore, auscultation only was employed by the author alone in studying the nature of the murmurs and the quality of the first heart sound in the mitral area. No claim is, therefore, made as to the correctness of some of the interpretations.

The mitral valve consists of many different parts which, by functioning together, allow the valve to act as a single unit. The anatomical sources of mitral valve dysfunction are, therefore, necessarily multiple.

A better understanding of the function of the normal and of the diseased valve may lead to more specific and better surgical techniques to restore normal valve function instead of the strong present-day trend to replace the whole mitral valve with a prosthesis.

The author wishes to express his appreciation to Prof. B. J. P. Becker, Department of Pathology, University of the Witwatersrand, Johannesburg, where all the pathological specimens were photographed and studied, for his permission to use the information obtained in this publication.

The assistance of Mr. Theo Marais, from our photographic department, is also greatfully acknowledged.

\section{REFERENCES}

Mounsey, P. (1953). The opening snap of mitral stenosis. Brit. Heart J., 15, 135.

Van der Spuy, J. C. (1958). The functional and clinical anatomy of the mitral valve. Brit. Heart J., $20,471$.

(1960). Mitral stenosis with posterior cusp incompetence. Read at the Second Bi-annual Meeting of the Southern Africa Cardiac Society at Cape Town, October, 1960. 